\title{
KONDISI LINGKUNGAN \\ PASCA PENGEBORAN SUMUR EKSPLORASI AT-1 DAN AT-2 \\ DI LAPANGAN PANAS BUMI ATADAI, LEMBATA, NUSA TENGGARA TIMUR
}

\author{
Oleh : \\ Soetoyo \\ Kelompok Program Penelitian Panas Bumi \\ Pusat Sumber Daya Geologi
}

SARI

Kegiatan pengujian uap/monitoring sumur eksplorasi panas bumi AT-1 dan AT-2 di Lapangan Panas Bumi Atadoli Nusa Tenggara Timur bertujuan untuk mendapatkan informasi tentang karakteristik sumur-sumur eksplorasi tersebut, sehingga dapat dipergunakan sebagai dasar dalam pengembangan selanjutnya.Hasil pengujian uap/monitoring menunjukan tekanan kepala sumur AT-1 adalah $7.0 \mathrm{~kg} / \mathrm{cm} 2$ sedangkan semur AT-2 adalah $0 \mathrm{~kg} / \mathrm{cm} 2$. Temperatur kepala sumur relatif sama dengan temperatur udara luar. Sumur eksplorasi AT-2 tidak menunjukan adanya aktifitas baik tekanan kepala sumur (TKS) maupun temperatur pada kepala sumur. Komposisi gas dari sumur eksplorasi AT-1 pada setiap kegiatan monitoring dilakukan didominasi oleh gas $\mathrm{CO} 2$ dan N2. Namun demikian dari dalam sumur tidak didapatkan fluida. Tidak terdapat penambahan/munculnya manifestasi baru pasca pemboran, baik pada pelataran sumur maupun pada daerah sekitar sumur eksplorasi.

\section{ABSTRACT}

The purpose of flow test/monitoring eksploration geothermal well AT-1 and AT-2, Atadei geothermal field, East Nusa Tenggara is to get characteristic information of those wells as a base to future field development. From steam flow test/well monitoring result, show that well head pressure of AT-1 is $7.0 \mathrm{KSc}$, but well head pressure of AT-2 is $0 \mathrm{KSc}$. Both of the well head temperatures as same as free air temperature. Exploration well of AT-2 did not show any activities,especially temperature or pressure of well head. In every flow test activities shown that the Gases composition, dominated by $\mathrm{CO} 2$ and N2. But in fact, from inside well there is no geothermal fluid. After exploration well activities, until now there is no new manivestation come out in the flat area or surrounded exploration wells.

\section{PENDAHULUAN}

Kegiatan pengujian uap/monitoring sumur eksplorasi panas bumi AT-1 dan AT-2 di Lapangan Panas Bumi Atadei Nusa Tenggara Timur telah mendapatkan informasi tentang karakteristik sumur-sumur eksplorasi tersebut, sehingga dapat dipergunakan sebagai dasar dalam pengembangan selanjutnya.Data yang disajikan dalam makalah ini, hasil kegiatan monitoring sumur/pengujian uap tahun 2006.

Untuk terlaksananya "good mining practice" merlu mendapatkan keselamatan kerja dan lingkungan di lapangan panas bumi, khususnya lapangan panas bumi Atedai, Kabupaten Lembata, Nusa Tenggara Timur.

Lapangan Panas Bumi merupakan daerah yang sarad terhadap gas, khususnya gas beracun, yang ditimbulkan oleh pengeboran sumur panas bumi..

Penyelidikan terdahulu, di lapangan panas bumi Atadoli, Kecamatan Atadoli, Kabupaten Lembata, Propinsi Nusa Tenggara Timur telah melakukan pemboran 2 Sumur Eksplorasi, AT-1 dan AT-2

Kegiatan ini merupakan salah satu upaya dalam rangka mengoptimalkan pemanfaatan sumber daya alam untuk memenuhi kebutuhan energi dimasa yang akan datang, dengan mengacu dan mengutamakan pada keselamatan kerja dan lingkungan di lapangan panas bumi.

Tulisan ini hasil pengujian sumur/monitoring sumur AT-1 dan AT-2 periode ke 3 tahun 2006, menginformasikan tentang pengaruh gas yang muncul baik melalui sumur eksplorasi maupun di lingkungan lapangan panas bumi Atadoli serta karakteristik sumur-sumur eksplorasi tersebut. 


\section{MAKALAH ILMIAH}

Tujuannya adalah untuk terhindar dari kecelakaan kerja maupun perusakan lingkungan yang ditimbulkan akibat pengeboran sumur dalam pengembangan selanjutnya.Lapangan Panas Bumi Atadai terdapat di $P$. Lembata (Gambar 1).

Sumur eksplorasi AT-1, secara administratif termasuk wilayah Kampung Kneping, Desa Nubaheraka, sedangkan AT-2 terletak di Kampung Lewopuho, Desa Atakore. Kedua lokasi sumur eksplorasi ini termasuk kedalam wilayah Kecamatan Atadei, Kabupaten Lembata, Propinsi Nusa Tenggara Timur. Secara geografis lokasi sumur eksplorasi AT- 1 terletak pada posisi 12331'55" BT, 0829'42" LS pada elevasi $606 \mathrm{~m}$ dpl. dan AT-2 pada 12332'17" BT, 0830'11" LS pada elevasi 552 m dpl.(Gambar 2)

\section{PENYELIDIK TERDAHULU}

Penyelidikan terdahulu yang berhubungan dengan kepanasbumian yang pernah dilakukan di daerah Atadei adalah: Inventarisasi Kenampakan Gejala Panas Bumi Santoso dkk. (1987)

Penyelidikan Terpadu Panas Bumi oleh Aswin , dkk. (2000); Survei Landaian Suhu ATD-1, oleh Suparman dkk. (2002); Survei Landaian Suhu ATD-2, oleh Nanlohi dkk. (2002), Pemboran Sumur Eksplorasi AT-1 Munandar dkk. (2004); dan AT-2 oleh Suparman dkk. (2004). Berdasarkan penelitian terdahulu tersebut diperoleh informasi kepanasbumian di daerah Atadei, diantaranya dikemukakan bahwa:Di Lapangan Panas Bumi Atadei dijumpai hot ground / steaming ground di desa Watuwawer (Karun), dengan temperatur 96-98oC, tipe air sulfat asam. Mata air panas lainnya bertemperatur rendah (32-45 oC), pH netral dan tipe bikarbonat untuk mata air panas Wai Krata, Wai Kowan, Wai Tupat, dan Wai Teba. Satu mata air menunjukkan tipe sulfat, $\mathrm{pH}$ netral dari mata air panas Waikating (Lewogeroma).

Telah dilakukan pemboran dua sumur landaian suhu(ATD-1 dan ATD-2) masing-masing dengan kedalaman 250 meter. Sumur ATD1 menggambarkan disekitar kaldera Watuwawer cukup prospek untuk dikembangkan. Sumur ATD-2 berdekatan dengan sesar Mauraja yang merupakan batas térluar daerah panas bumi yang dapat dikembangkan.
Dua sumur eksplorasi lebih dalam yaitu AT-1 dan AT-2 dengan kedalaman masing-masing $830,5 \mathrm{~m}$ dan $750,5 \mathrm{~m}$ telah dilakukan di daerah Kneping dan Watuwawer.: Hasil pengujian uap/monitoring periode kedua tahun 2006 sumur eksplorasi AT-1 dan AT-2 menunjukan tekanan kepala sumur AT-1 adalah $7.0 \mathrm{~kg} / \mathrm{cm} 2$ sedangkan sumur AT-2 adalah $0 \mathrm{~kg} / \mathrm{cm} 2$. Temperatur kepala sumur relatif sama dengan temperatur udara luar. Sedangkan sumur eksplorasi AT-2 tidak menunjukan adanya aktifitas baik tekanan kepala sumur (TKS) maupun temperatur pada kepala sumur.

Berdasarkan kandungan gas terutama pada sumur eksplorasi AT-1 pada monitoring periode kedua ini didominasi oleh gas $\mathrm{CO} 2$, dimana gas tersebut merupakan gas yang lazim terdapat pada daerah vulkanik. Namun demikian dari sumur tidak didapatkan fluida.

Tidak terdapat penambahan/munculnya manifestasi baru pasca pemboran, baik pada pelataran sumur maupun pada daerah sekitar sumur eksplorasi.

\section{HASIL PENYELIDIKAN}

Hasil pengujian uap sumur/monitoring periode ketiga tahun 2006, sumur AT-1 dan AT-2 Atadei adalah sebagai berikut.

\section{Sifat Fisik dan Kimia Sumur}

Monitoring sifat fisik dan sifat kimia dilakukan untuk mengetahui kondisi fluida sumur yang dapat dilihat dari temperatur, tekanan serta komposisi kimia fluida sumur. Data sifat fluida tersebut dapat dipergunakan lebih lanjut untuk analisis dalam pengembangan lapangan panas bumi tersebut.

\section{Sifat Fisik}

Kegiatan monitoring yang dilakukan dalam rangka mengetahui sifat fisik sumur meliputi: pengamatan TKS (Tekanan Kepala Sumur), pengukuran temperatur fluida di kepala sumur dan pengamatan kondisi sumur. Dari hasil pengamatan didapatkan bahwa tekanan kepala sumur (TKS) sumur AT 1 adalah 7 barg, sedangkan pada sumur AT 2 adalah 0 barg. Pengukuran temperatur tidak dilakukan karena gas yang keluar dari 


\section{MAKALAH ILMIAH}

sumur menimbulkan bau yang sangat kuat, sehingga dikhawatirkan merupakan gas beracun. Hasil pengamatan, dapat diketahui bahwa temperatur pada kedua kepala sumur relatif sama dengan temperatur udara sekitar. Hal ini menunjukkan bahwa tekanan kepala sumur pada sumur AT 1 yang terbaca pada $7.0 \mathrm{~kg} / \mathrm{cm} 2$ tidak disebabkan oleh tekanan uap panas dari dasar sumur, melainkan oleh gas lain yang naik ke permukaan dari dasar lubang sumur dan kemudian terakumulasi (gambar 3).

Pada saat master valve kepala sumur dibuka, terlihat semburan gas keluar (gambar 4). Semburan gas tersebut hanya berlangsung kurang dari satu menit dan TKS yang semula menunjukkan angka 7 barg turun hingga menjadi 0 barg (gambar 5)

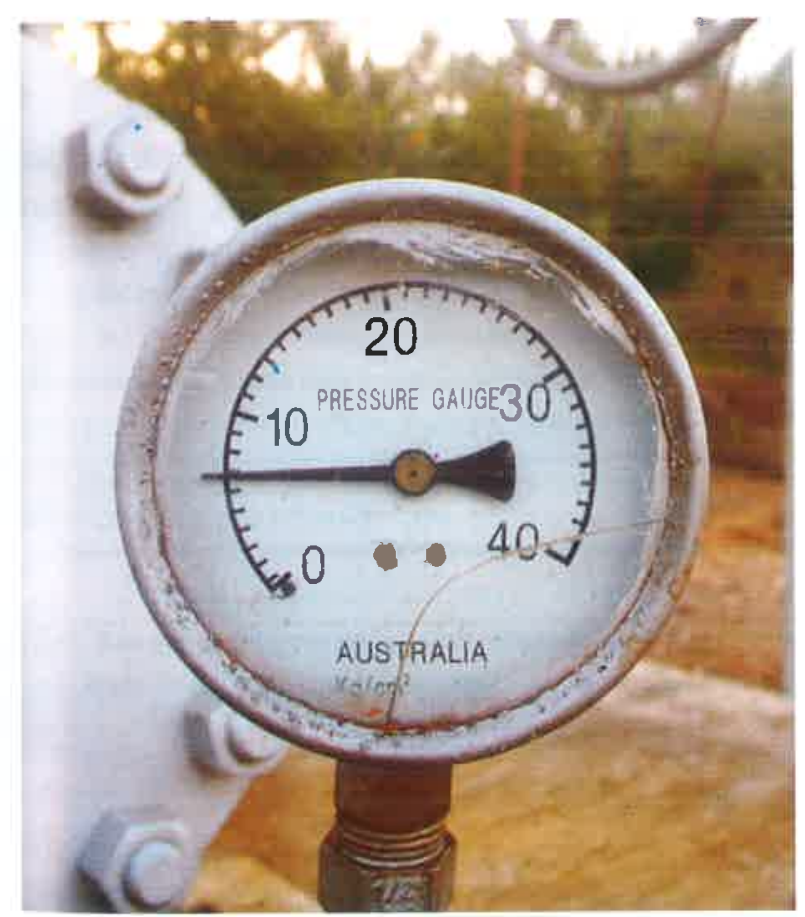

Gambar 3, TKS sumur Eksplorasi AR-1

Lapangan Panas Bumi Atadei, Kabupaten Lembata

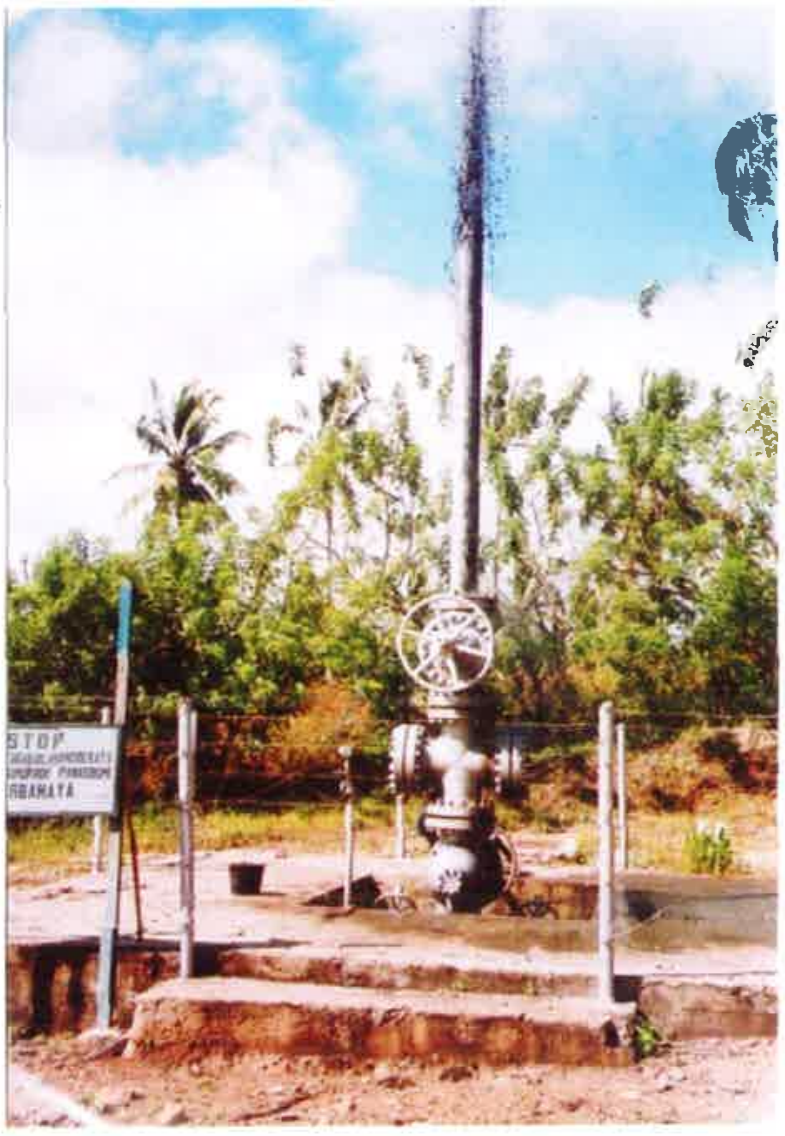

Gambar 4. Instalasi Sumur Eksplorasi AT-1

Kaoangan Panas Bumi Atadei, Lembata, NTT

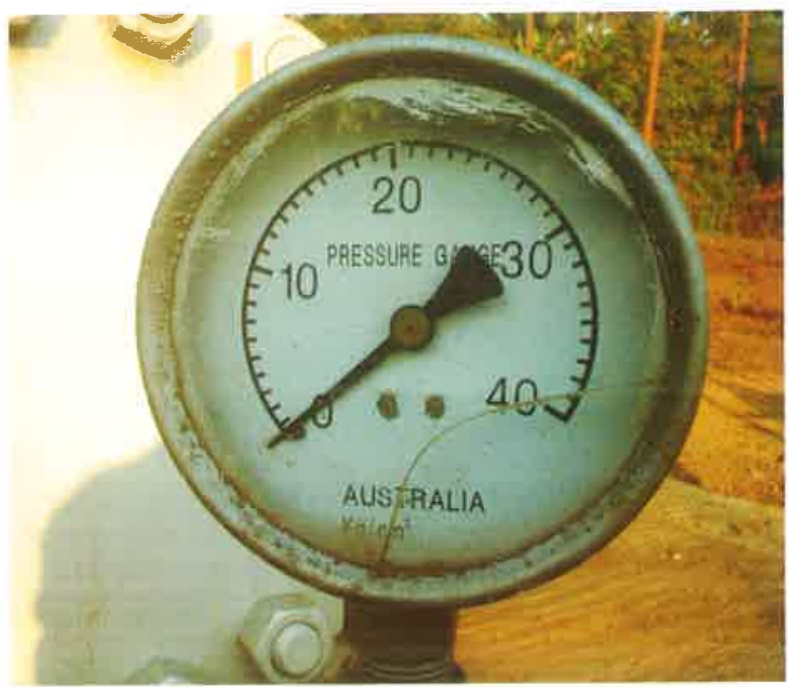

Gambar 5. TKS sumur Eksplorasi AT-1

Lapangan Panas Bumi Atadei, Kabupaten Lembata, NTT setelah Master Valve dibuka 


\section{MAKALAH ILMIAH}

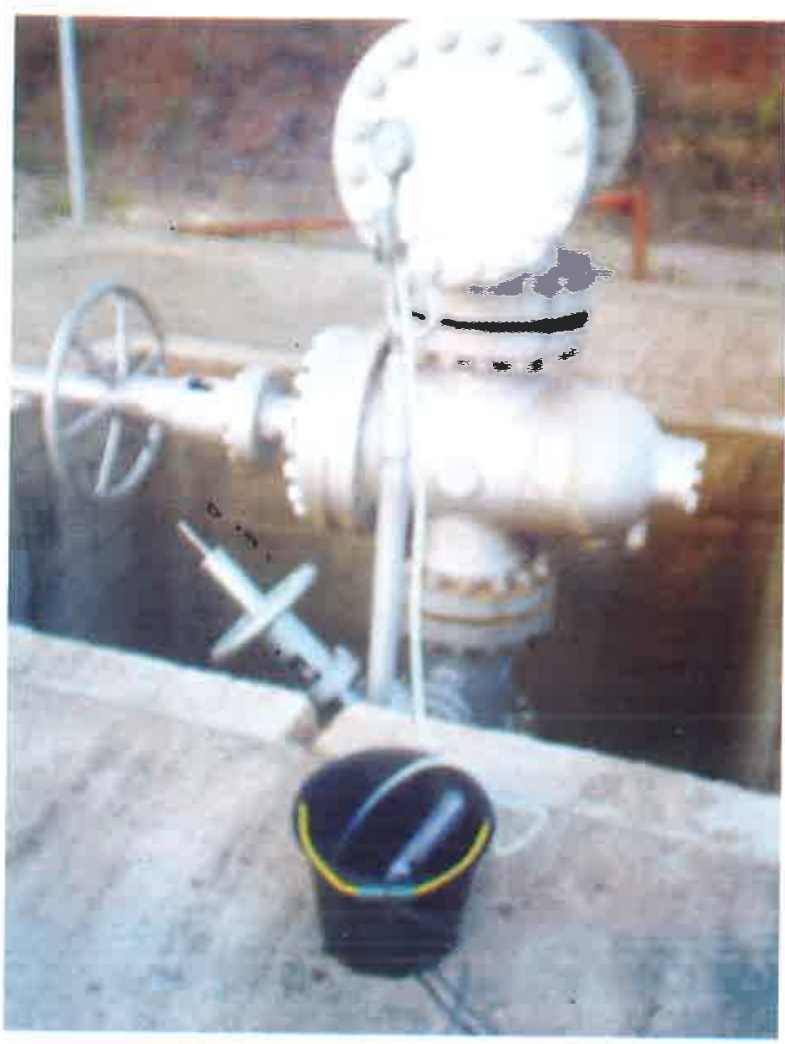

Gambar 6. Instalasi pengambilan sampel gas sumur Eksplorasi AT-1

Lapangan Panas Bumi Atadei, Lembata, NTT

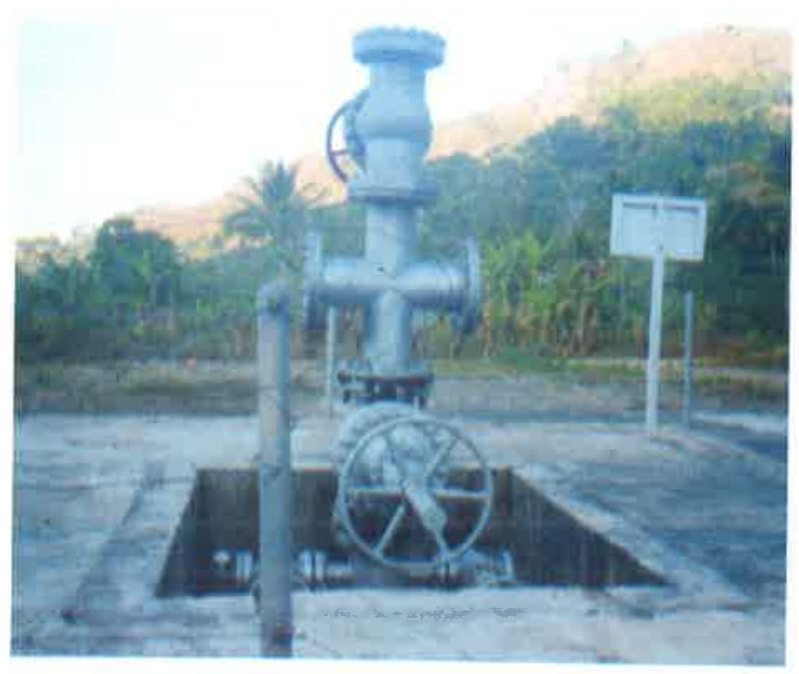

Gambar 7. Instalasi sumur Eksplorasi AT-2 Lapangan Panas Bumi Atadei, Kabupaten Lembata, NTT

\section{Sifat Kimia}

Kegiatan-kegiatan lapangan dalam monitoring sifat kimia sumur AT-1 dan AT-2 tahun 2006 meliputi: Pengukuran temperatur manifestasi serta konsentrasi gas $\mathrm{CO} 2, \mathrm{H} 2 \mathrm{~S}, \mathrm{CO}$ dan $\mathrm{NH} 3$ di sekitar manifestasi Karun. Pengambilan contoh gas dalam uap (NCGS) dari sumur uji AT-1 dan AT-2 dengan mempergunakan tabung vakum yang telah diisi $50 \mathrm{ml}$ larutan $\mathrm{NaOH}(25 \%)$ serta divakumkan (gambar6)

Dari pengukuran pada daerah manifestasi Karun didapatkan temperatur manifestasi berkisar antara 98,6 oC sampai 99,3 oC,. Sedangkan dari hasil pengukuran konsentrasi gas pada daerah manifestasi tersebut didapatkan konsentrasi gas $\mathrm{CO} 2$ dalam udara $0.20 \%$, gas $\mathrm{H} 2 \mathrm{~S} 6 \mathrm{ppm}$, gas $\mathrm{CO} 12$ ppm, dan gas $\mathrm{NH} 3$ tidak terdeteksi.

Hasil analisis laboratorium terhadap sampel gas yang diambil dari sumur AT-1 menunjukkan bahwa konsentrasi gas CO2 sangat tinggi hingga 72,16\% mol. Hasil lengkap dari analisis gas terlihat pada tabel berikut.

Tabel 1. Hasil analisis kimia gas sumur AT-1 pada monitoring periode ke-3

\begin{tabular}{|c|c|}
\hline Senyawa & $\begin{array}{c}\text { Konsentrasi (\% } \\
\text { mol) }\end{array}$ \\
\hline \hline $\mathrm{H}_{2}$ & 1,80 \\
\hline $\mathrm{O}_{2}+\mathrm{Ar}$ & 4,24 \\
\hline $\mathrm{N}_{2}$ & 20,43 \\
\hline $\mathrm{CH}_{4}$ & 0,014 \\
\hline $\mathrm{CO}_{2}$ & 72,16 \\
\hline $\mathrm{SO}_{2}$ & 0,00 \\
\hline $\mathrm{H}_{2} \mathrm{~S}$ & 0,00 \\
\hline $\mathrm{HCl}$ & 1,34 \\
\hline $\mathrm{NH}_{3}$ & 0,02 \\
\hline
\end{tabular}

\section{Manifestasi Panas Bumi}

Manifestasi panas bumi di daerah Atadei terdiri dari fumarola, kubangan lumpur panas, tanah panas, mata air panas, serta batuan ubahan dan endapan 


\section{MAKALAH ILMIAH}

belerang. Terbentuknya manifestasi yang bervariasi ini terjadi sejak sebelum dilakukan pemboran panas bumi, seperti lokasi manifestasi panas bumi berupa tanah panas "Karun" yang terletak berdekatan dengan sumur AT-2. Lebih kurang 250 meter mengarah ke bagian barat, terdiri dari fumarola, kubangan Lumpur panas, tanah panas, batuan ubahan dan endapan belerang.

\section{Manifestasi Sebelum Pemboran}

Manifestasi panas bumi di Atadei yang sudah muncul sebelum dilakukan pemboran dan sampai sekarang masih dapat diamati yaitu manifestasi panas bumi Karun yang terletak di bagian barat daya desa Atakore (gambar 8). Jenis manifestasi panas bumi di daerah ini terdiri dari fumarola, kubangan lumpur panas, tanah panas dan batuan ubahan.

Temperatur manifestasi Karun terukur antara 98,6 oC sampai 99,3 oC, pada temperatur udara di sekitar lokasi 24,3 C (gambar 9). Di lokasi yang lain terdapat manifestasi berupa mata air panas Wai Krata yang airnya tidak berwarna dan tidak terlalu panas, sehingga digunakan sebagai tempat pemandian sederhana oleh penduduk setempat. Temperatur air panas tidak lebih dari $36 \mathrm{C}$ pada temperatur udara lokasi setempat $23 \mathrm{C}$

\section{Manifestasi Pasca Pemboran}

Setelah dilakukan pemboran sumur eksplorasi AT-1 dan AT-2 tidak terjadi perubahan di sekitar sumur bor, dan tidak terdapat pemunculan manifestasi yang baru.

Pada manifestasi Karun yang terdapat di sekitar sumur AT-2, terlihat adanya sublimasi belerang. Bualan manifestasi diikuti suara gelembung (bubble) yang tercampur dengan lumpur panas yang relatif kuat.

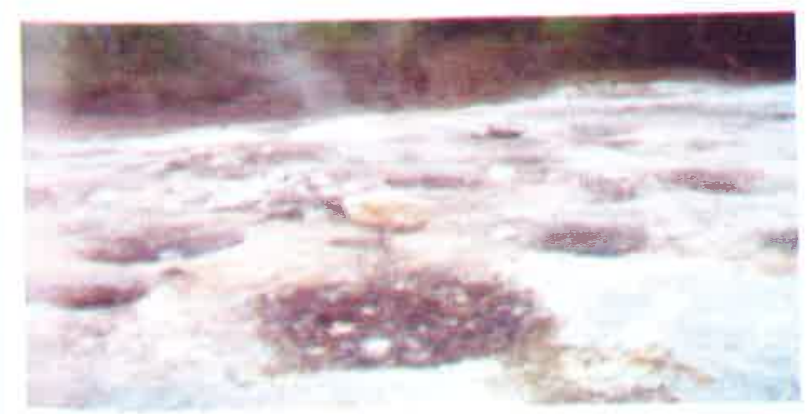

Gambar 8 Mnaifestasi Tanah Panas "Karun" desa Atakone

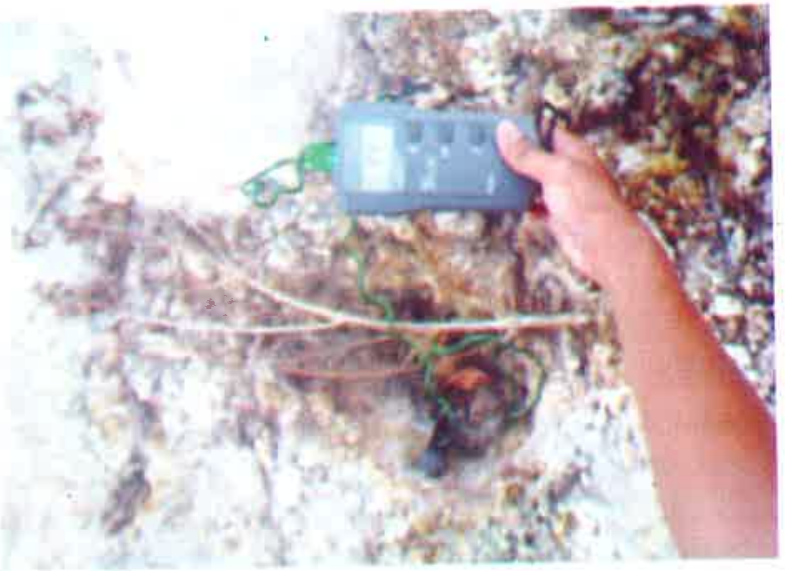

Gambar 9 Pengukuran temperatur manifestasi tanah panas "Karun"

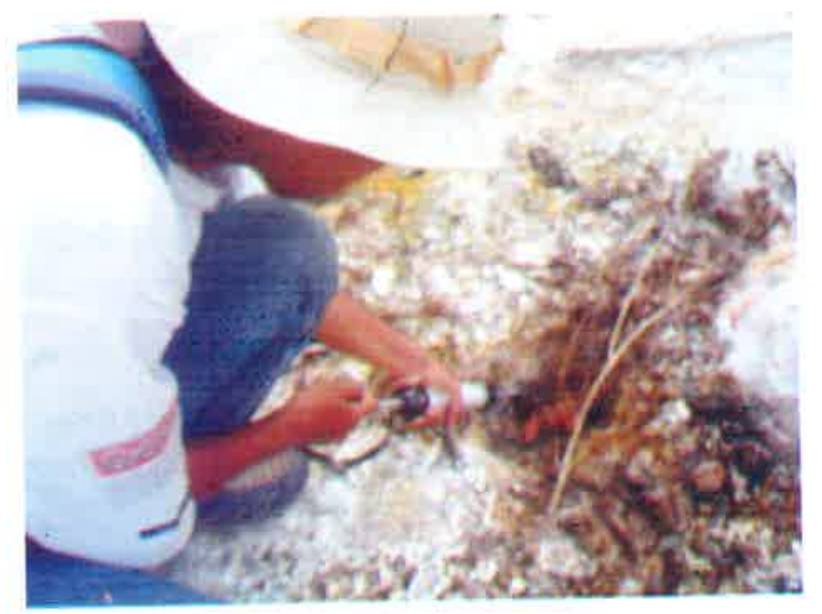

Gambar 10. Pengukuran Kandungan gas H2S dengan gas Detektor

Kitagawa pada Manifestasi

\section{Lingkungan}

Kondisi lingkungan di sekitar lokasi sumur panas bumi AT-1 dan AT-2 sesudah pengeboran tidak mengalami perubahan yang berarti. Di sekitar lokasi sumur tidak dijumpai adanya manifestasi baru baik berupa mata air panas, tanah panas, lumpur panas dan sublimasi belerang. Pengamatan dan pengukuran temperatur terhadap kelompok manifestasi yang ada sebelum pemboran sumur AT-1 dan AT-2 dilakukan sampai sekarang dan pada monitoring periode ketiga ini tidak dijumpai banyak perubahan.

\section{PEMBAHASAN}

Hasil kegiatan monitoring sumur eksplorasi AT-1 


\section{MAKALAH ILMIAH}

dan AT-2 yang dilakukan tahun 2006 berupa data Fisik sumur, komposisi kimia uap sumur, dan kondisi manifestasi panas bumi di sekitar lokasi sumur.

Pada pengujian uap/monitoring sumur eksplorasi AT-1 dan AT-2, hasil pengukuran TKS (Tekanan Kepala Sumur) dan pengamatan kondisi sumur menunjukkan bahwa TKS pada sumur AT 1 adalah 7.0 $\mathrm{Kg} / \mathrm{Cm} 2$, sedangkan pada sumur AT 2 adalah 0 barg. Pengukuran temperatur pada flow line kepala sumur tidak dapat dilakukan karena adanya bau busuk yang demikian kuat dari gas yang keluar dari sumur, namun demikian dari hasil pengamatan dapat diketahui bahwa temperatur pada kedua kepala sumur relatif sama dengan temperatur udara sekitar.

Tekanan kepala sumur pada sumur AT 1 sebesar $7,0 \mathrm{Kg} / \mathrm{Cm} 2$ ini bukan disebabkan oleh tekanan uap panas dari dasar sumur, melainkan oleh gas lain yang naik kepermukaan dari dasar lubang sumur kemudian terakumulasi. Hal ini terlihat ketika master valve dibuka, dalam waktu kurang dari satu menit tekanan di kepala sumur telah menjadi $0 \mathrm{Kg} / \mathrm{Cm} 2$.

Akumulasi gas yang mencapai tekanan $7.0 \mathrm{KSC}$ adalah sebagai akibat aktivitas vulkanisme yang terjadi dimasa lampau dan menyebabkan terjadinya kantongkantong (cavity) yang berisi berbagai campuran gas antara lain $\mathrm{CO} 2$ dan $\mathrm{H} 2 \mathrm{~S}$ kemudian, melalui struktur join atau rekahan dibawah permukaan menerobos keluar melalui dasar lubang bor dan terakumlasi pada kepala sumur. Kondisi sumur AT 2 tidak menunjukkan adanya perbedaan yang diakibatkan oleh suatu aktivitas tertentu.

Hasil analisis gas di lapangan menunjukkan bahwa komposisi gas dari sumur AT-1 didominasi oleh gas $\mathrm{CO} 2$ yaitu sebesar $72,16 \%$ mol. Kondisi demikian terjadi apabila sumur ditutup sehingga terjadi konsentrasi gas tersebut di dalam kepala sumur, dan kepala sumur telah menunjukkan tekanan sebasar $7.0 \mathrm{KSC}$.

Gas lain yang juga dominan adalah N2 yang konsentrasinya mencapai $20,43 \%$ mol. Gas-gas tersebut kemungkinan berasal dari bagian bawah dasar lubang bor yang naik ke permukaan melalui rekahan atau join, kemudian terperangkap/terakmulasi pada lubang bor. Hal ini menunjukan bahwa fluida yang keluar dari sumur eksplorasi AT-1 bukanlah uap air seperti yang diharapkan, namun merupakan gas-gas yang terperangkap di lubang bor.

Konsentrasi gas pada daerah manifestasi sekitar sumur AT-1 dan AT-2 menunjukkan konsentras gas $\mathrm{CO} 2$ dalam udara $0.1 \%$, gas $\mathrm{H} 2 \mathrm{~S}$ tidak terdeteksi, gas $\mathrm{CO} 6$ ppm, dan gas $\mathrm{NH} 3$ tidak terdeteksi, konsentrasi ini masih di bawah ambang batas.

Hasil analisis gas di lapangan menunjukkan bahwa komposisi gas dari sumur AT-1 didominasi oleh gas $\mathrm{CO} 2$. Gas tersebut kemungkinan berasal dari bagian bawah dasar lubang bor yang naik ke permukaan melalui rekahan atau join, kemudian terperangkap/terakmulasi pada lubang bor. Hal ini menunjukan bahwa uap sumur eksplorasi AT-1 adalah uap kering.

Kondisi lingkungan sekitar lokasi sumur panas bumi AT-1 dan AT-2 pasca pemboran tidak mengalami banyak perubahan. Di sekitar lokasi sumur tidak dijumpai adanya manifestasi baru baik berupa mata air panas, tanah panas, lumpur panas dan sublimasi belerang. Pengamatan dan pengukuran temperatur terhadap kelompok manifestasi yang ada sebelum pemboran sumur AT-1 dan AT-2 dilakukkan sampai pada monitoring periode akhir 2006 tidak mengalami perubahan apa-apa.

\section{KESIMPULAN}

Hasil pengujian uap/monitoring periode ketiga tahun 2006 sumur eksplorasi AT-1 yang dilaksanakan akhir 2006, menunjukan minimum tekanan kepala sumur AT-1 adalah $7.0 \mathrm{~kg} / \mathrm{cm} 2$ sedangkan semur AT-2 adalah 0 $\mathrm{kg} / \mathrm{cm} 2$. Temperatur kepala sumur AT-1 dan AT-2 relatif sama dengan temperatur udara luar.

Berdasarkan kandungan gas terutama pada sumur eksplorasi AT-1 pada monitoring periode akhir 2006 didominasi oleh gas $\mathrm{CO} 2$, dimana gas tersebut merupakan gas yang lazim terdapat pada daerah vulkanik. Namun demikian dari sumur tidak didapatkan fluida yang berupa uap air.

Tidak terdapat penambahan/munculnya manifestasi baru pasca pemboran, baik pada pelataran sumur maupun pada daerah sekitar sumur eksplorasi.

Tidak terdapat pengaruh baik gas maupun pengaruh lain terhadap lingkungan akibat pengeboran sumur eksplorasi AT-1 dan AT-2 di lapangan panas bumi Atadai, Lembata, Nusa Tenggara Timur. 


\section{MAKALAH ILMIAH}

\section{ACUAN}

Aswin, D., (2000), Penyelidikan Terpadu Daerah Panas Bumi Atadei, Kabupaten Lembata-Nusa Tenggara Timur.

Giggenbach, W.F., dan Goguel(1988), Methods for the collection and Analysis of Geothermal and volcanic water and gas sampels, Report No. CD 2387 Chemistry Division Department of Scientific and Industrial Research, Petone, N.Z. Report No. CD 2387.

Munandar, A., dkk., (2004), Laporan Pengeboran Sumur Eksplorasi-Semi Eksploitasi AT-1 \& AT-2, Lapangan Panas Bumi Atadei, Kabupaten Lembata-Nusa Tenggara Timur.

Nanlohy, F., (2002), Laporan Survei Landaian suhu Sumur ATD-2, Lapangan Panas Bumi Atadei, Kabupaten Lembata, Nusa Tenggara Timur.

Santoso, M.S., dkk., (1987), Inventarisasi Kenampakan Gejala Panas Bumi di Sekitar Flores Timur, P. Lomblen, P. Adonara, P. Solor, NTT, Direktorat Vulkanologi, Bandung.

Sitorus, K., (2002), Proposal Pengeboran Sumur Landaian Suhu ATD-1 dan ATD-2, Daerah Panas Bumi Atadei, Kabupaten Lembata-Nusa Tenggara Timur.

Sundhoro.H., (1997), Pemetaan Geologi Panas Bumi Daerah Watukuba-Atalojo, Atadei-P.Lomblen, Kabupaten Flores Timur, Nusa Tenggara Timur.

Suparman, (1997), Laporan Penyelidikan Geokimia Panas Bumi Daerah Atadei, P. Lomblen, Nusa Tenggara Timur.

Suparman, dkk, (2002), Laporan Survei Landaian Suhu Sumur ATD-1, Lapangan Panas BumiAtadei, Kabupaten LembataNusa Tenggara Timur.

Sulaeman.B, dkk, (Juni, 2005), Laporan Pengujian Uap/Monitoring Periode Ke 1 Sumur Eksplorasi AT-1 dan AT-2 (tidak dipublikasikan).

Suparman, dkk., (2004), Laporan Pengeboran Sumur Eksplorasi-Semi Eksploitasi AT2, Lapangan Panas Bumi Atadoli, Kabupaten Lembata-Nusa Tenggara Timur.

Syuhada, A, dkk, (2005) Laporan Pengujian Uap/Monitoring Sumur Eksplorasi AT-1 dan AT-2 (tidak dipublikasikan) 


\section{MAKALAH ILMIAH}
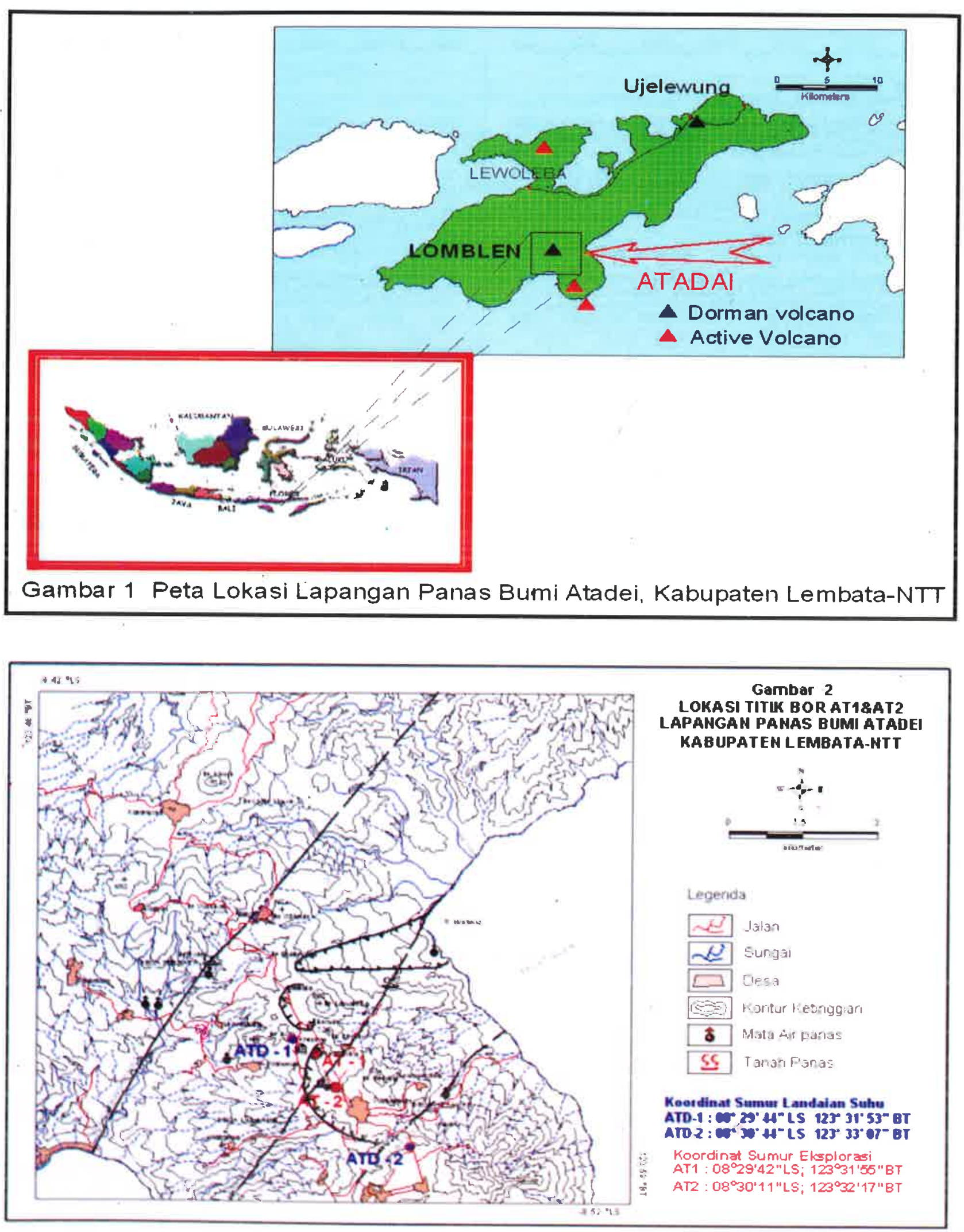